doi: To be issued soon

\title{
Leaf composition and productivity of yellow passion fruit (Passiflora edulis Sims.) Access "Guinezinho" in soil with bovine biofertilizer and nitrogen
}

\author{
Adriana Araújo Diniz ${ }^{1}$, Lourival Ferreira Cavalcante ${ }^{2}$, Antônio Gustavo de Luna Souto ${ }^{3 *}$, Eudes de Almeida \\ Cardoso ${ }^{4}$, Patrícia Carneiro Souto ${ }^{5}$, Rejane Maria Nunes Mendonça ${ }^{3}$, Nildo da Silva Dias ${ }^{4}$
}

${ }^{1}$ State University of Maranhão, Departament of Agronomy, Balsas city, Maranhão State, Brazil.

${ }^{2}$ Federal University of Paraíba, Department of Soil and Rural Engineering, Areia city, Paraíba State, Brazil.

${ }^{3}$ Federal University of Paraíba, Departament of Plant Science, Areia city, Paraíba State, Brazil.

${ }^{4}$ Federal Rural Semiarid University, Agricultural Science Center, Mossoró city, Rio Grande do Norte State, Brazil.

${ }^{5}$ Federal University of Campina Grande, Forest Engineering Academic Unit, Patos city, Paraíba State, Brazil.

\section{*Corresponding author: gusluso@hotmail.com}

\section{Abstract}

The use of alternative inputs, derived from the fermentation of fresh organic matter, exerts significant importance in the pasiculture in partial substitution to synthetic commercial fertilizers.An experiment was conducted in the period from 2013 to 2014 to evaluate the effects of bovine biofertilizer and nitrogen, on leaf mineral composition of macronutrients, micronutrients and sodium and productivity of yellow passion fruit. The treatments were arranged in randomized blocks with three replicates and nine plants per plot, using the factorial scheme $5 \times 2$, referring to the bovine biofertilizer applied to the soil in the liquid form (B) in the proportions in water $(W)$ of $O(O B+4 W) ; 25(1 B+3 W) ; 50(2 B+2 W) ; 75(3 B+1 W)$ and $100 \%(4 B+0 W)$, in the soil without and with nitrogen. The bovine biofertilizer was applied at level of $4 \mathrm{~L} \mathrm{plant}^{-1}$ of each proportion in water, at 7 days before and 90 days after transplanting of the seedlings with aged 50 days from fruit seeds well developed in size, oblique shape and mass and the nitrogen was applied to every 30 days after transplantation of the seedlings until the end of the experiment. The plants, in general, were adequately supplied in $\mathrm{N}, \mathrm{Mg}, \mathrm{S}, \mathrm{B}, \mathrm{Cu}$ and $\mathrm{Zn}$, but deficient in $\mathrm{P}, \mathrm{K}, \mathrm{Ca}, \mathrm{Cu}, \mathrm{Fe}$ and $\mathrm{Mn}$ at the beginning of flowering. The highest fruit production of $30.75 \mathrm{t} \mathrm{ha}^{-1}$ were obtained from the plants on soil with $100 \%$ of bovine biofertilizer and with nitrogen. Due to the superiority of fruit productivity in plants with biofertilizer bovine and nitrogen compared to those treated with only bovine biofertilizer, it is verified that the organic input does not substitute the nitrogen for the cultivation of the yellow passion fruit.

Keywords: Passiflora edulis L., organic input, urea, plant nutrition.

Abbreviations: N_Nitrogen; P_Phosphorus; K_potassium; $\mathrm{Ca}^{2+}$ _Calcium; $\mathrm{Mg}^{2+}$ _Magnesium; S_Sulfur; B_Boron; Cu_Copper; Mn_ Manganese; Fe_Iron; Zn_Zinc; Na_Sodium; B_Biofertilizer; W_Water; DAT_days after transplantation; Fig_Figure; OM_Organic

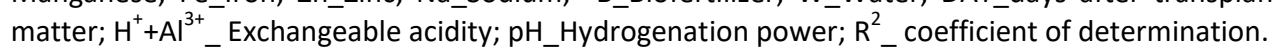

Introduction

Yellow passion fruit is a native tropical fruit tree with economic importance in the fruit production system of Brazil in the last 40 years and currently occupies a prominent place in the national fruit growing (IBGE, 2017; Melleti et al., 2011). The preference for the consumer, low planting time, small and medium-sized crop cultivation, rapid return on investment and distributed income during most of the year makes it attractive and viable to growers (Meletti, 2011; Cavichioli et al. al., 2017).

Among the factors that contribute to the expansion of the cultivated area with passion fruit, investments are included in research aimed at soil fertility and mineral nutrition of plants (Cavalcante et al., 2012a; Cavalcante et al., 2012b). In recent years, mineral nutrition has been seen as one of the factors that contribute most to the increase in productivity and quality of yellow passion fruit (Nascimento et al., 2011; Venâncio et al., 2013), which is still low and (Furlaneto et al.,
2014), mainly in soils of tropical regions that are generally of low and medium fertility (Natale et al., 2012).

Among the nutrients most absorbed by yellow passion fruit, nitrogen $(N)$ is the most absorbed by the crop (Venâncio et al., 2013). The essentiality of nitrogen is attributed to the formation of several compounds essential for growth and production, highlighting proteins, photosynthetic pigments and the constituents of nitrogenous bases of nucleic acids (Taiz et al., 2017).

The nutritional supply to yellow passion fruit is made with synthetic inputs of proven efficacy, but the high price of these inputs in the market (Menezes et al., 2012) and the national and international consumer demand for products without the use of synthetic commercial inputs justify (Pacheco et al., 2004). In addition, the use of the nutrient supplementation method in the treatment of plant diseases has been proposed. Organic residues of animal origin may contribute to the partial substitution of mineral fertilization, 
increasing soil fertility, solubility and availability of nutrients already existing in the soil (Lehmann and Kleber, 2015).

In this context, the bovine biofertilizer is a source of microorganisms that biologically solubilize macro- and micronutrient-containing compounds, increasing plant availability (Ahmed et al., 2011, Mohammadi and Sohrabi, 2012). In addition, the application of bovine biofertilizer to soil improves physical properties, increases water dynamics and macroporous space that stimulates root growth (Li et al., 2017).

In the literature, there is information that justifies the use of the bovine biofertilizer, in isolation and simultaneously with mineral fertilizers, in the nutritional status and yield of some crops, including yellow passion fruit (Silva Júnior et al., 2013 Oliveira et al., 2014; Aguiar et al., 2017). The innovative character refers to the possibility of reducing the costs of production in partial substitution of the bovine biofertilizer to the synthetic mineral fertilizers like the nitrogen for the yellow passion fruit. The objective of this study was to evaluate the effects of biofertilizer bovine and nitrogen on leaf nutrient content and yield of yellow passion fruit.

\section{Results and Discussion}

\section{Macronutrient contents in leaf dry matter of yellow passion} fruit plants

Except for calcium and sulfur leaf composition, the interaction between bovine biofertilizer and nitrogen did not significantly interfere in the leaf accumulation of the other macronutrients. The levels of $\mathrm{N}$ and $\mathrm{P}$ were influenced by the isolated action of the bovine biofertilizer, it was also verified that the potassium and magnesium contents did not respond to the effects of the bovine and nitrogen biofertilizer doses nor the interaction between them (Additional Table 3). Except for iron that was not interfered with by any source of variation, the other micronutrients and sodium and plant productivity were influenced by the interaction between bovine biofertilizer and nitrogen.

The absence of significant effects of the sources of variation and the interaction between them in potassium and magnesium leaf contents, despite the high concentration of $\mathrm{K}^{+}$and $\mathrm{Mg}^{2+}$ in cattle manure and $\mathrm{K}^{+}$was provided from 90 DAT as chloride potassium, may be a response of the antagonistic interaction between $\mathrm{Ca}^{2+}$ and $\mathrm{K}^{+}$and $\mathrm{Mg}^{2+}$ (Ranade-Malvi, 2011), interfering with the availability of both nutrients to plants.

The $\mathrm{N}$ contents in the leaf dry matter of the plants (Fig. 1A) did not fit any regression model, so they were represented by the mean value of $40.62 \mathrm{~g} \mathrm{~kg}^{-1}$ of $\mathrm{N}$. This average content, although inferior to the amplitude of 46.5 to $50.8 \mathrm{~g} \mathrm{~kg}^{-1}$ reported by Nascimento et al. (2011), similar to the $40 \mathrm{~g} \mathrm{~kg}-1$ of $\mathrm{N}$ in passion fruit developed in the soil with bovine biofertilizer and fertilization with NPK (Cavalcante et al., 2012b) and is included in the range of 40 to $50 \mathrm{~g} \mathrm{~kg}^{-1}$, considered adequate by Malavolta et al. (1997) for culture at the beginning of flowering.

The nutritional adequacy of the plants in the macronutrient is a response to the amount of nutrient contained in the bovine biofertilizer applied a week before and every 90 DAT in the area of passion fruit projection, since it is the nutrient most absorbed and required by the plants (Venâncio et al., 2013). According to Lehmann and
Kleber (2015), organic residues from the bovine biofertilizer exert beneficial effects on the soil, increasing fertility, including the availability of nitrogen to the plants.

Although the increase of the biofertilizer applied to the soil increased the levels of $P$ in leaves from 2.55 to $3.45 \mathrm{~g} \mathrm{~kg}^{-1}$ (Fig. 1B), the plants at the beginning of flowering were deficient in the nutrient. Comparison, the values resemble the average content of $3.3 \mathrm{~g} \mathrm{~kg}^{-1}$ (Rodrigues et al., 2009), the variation of 2.5-3.0 $\mathrm{g} \mathrm{kg}^{-1}$ (Nascimento et al., 2011) and $2.8 \mathrm{~g}$ $\mathrm{kg}^{-1}$ (Cavalcante et al., 2012b) in yellow passion fruit plants established in the soil with bovine biofertilizer and mineral fertilization with NPK.

When considering that the plants produced at an adequate level in the respective articles mentioned above and in the work under consideration up to $30 \mathrm{t} \mathrm{ha}^{-1}$, superiority is verified in comparison to the national average that is below $15 \mathrm{t} \mathrm{ha}^{-1}$ (IBGE, 2017). This productivity evidences that the extraction of $P$ by the plants may have been enough to the growth, development of the vegetative, reproductive organs and formation of the fruits.

Potassium leaf contents did not respond to the effects of any of the sources of variation and had a mean leaf content of $13.93 \mathrm{~g} \mathrm{~kg}^{-1}$ (Additional Table 3). The value indicates that yellow passion fruit plants were deficient in the macronutrient, which is potassium-balanced when it accumulates between 25 and $35 \mathrm{~g} \mathrm{~kg}^{-1}$ of $\mathrm{K}^{+}$in the leaf dry matter. The results express that the bovine biofertilizer adds potassium, however, the content of the element in the input is considered median (Additional Table 1), which entails in nutrient deficiency to the plants. In addition to these inconveniences, the addition of bovine biofertilizer at 90 DAT may have increased the population of microorganisms (Marrocos et al., 2012) that consume potassium reducing availability to plants.

In spite of the increase of the bovine biofertilizer, in the soil without nitrogen, to increase the foliar calcium contents from 3.96 to $4.55 \mathrm{~g} \mathrm{~kg}^{-1}$ in the treatments without (zero) and with the maximum estimated dose of $38.9 \%$ of the organic input; while the increase of the biofertilizer concentration from 0 to $100 \%$ linearly reduced the accumulated levels of the macronutrient in the soil plants with nitrogen (Fig. 1C) from 6.10 to $4.25 \mathrm{~g} \mathrm{~kg}^{-1}$. The increase of $\mathrm{Ca}^{2+}$ was $14.9 \%$ and the decrease of $25.4 \%$, respectively, between the plants of the soil without and with addition of nitrogen, but always with superiority in the treatments with nitrogen, but is far below the amplitude of 15 to $20 \mathrm{~g} \mathrm{~kg}^{-1}$ presented by Malavolta et al. (1997) as sufficient for yellow passion fruit. Similar behavior was also recorded by Rodrigues et al. (2009) and Nascimento et al. (2011) in passion fruit plants under increasing levels of biofertilizer and mineral fertilization with NPK.

Even considering the total calcium added by the nutrient rich organic matter $\left(8.05 \mathrm{cmolc} \mathrm{dm}^{-3}\right)$ in the preparation of the pits, two additions of bovine biofertilizer, a week before and 90 DAT that also added the element (Additional Table 2), and a $90 \%$ DAT fertilization with $20 \mathrm{~g} \mathrm{plant}^{-1}$ of $\mathrm{P}_{2} \mathrm{O}_{5}(20 \%$ $\left(\mathrm{Ca}^{2+}\right.$ ) were not enough to adequately supply the plants in calcium. However, it is important to note that in the field, the plants did not emit visual symptoms characteristic of calcium deficiency. According to Malavolta et al. (1997) and Radane-Malvi (2011), the low levels may be a consequence of antagonistic effects of $\mathrm{Ca}^{2+}$ with other elements such as 
$\mathrm{Na}^{+}$and $\mathrm{K}^{+}$in the soil, promoting reduction in the absorption of the element by plants.

Like potassium, foliar magnesium contents were not influenced by the sources of variation studied, but the plants were nutritionally balanced in the nutrient. The mean value observed was $3.62 \mathrm{~g} \mathrm{~kg}^{-1}$ between the plants of the treatments with biofertilizer, regardless of the application of nitrogen or not, and exceeds the variation of 1.5 to $3.5 \mathrm{~g} \mathrm{~kg}^{-1}$ as suitable for cultivation (Malavolta et al., 1997).

The increase of the doses of bovine biofertilizer inhibited the accumulation of $S$ in the yellow passion fruit leaves in the soil plants without nitrogen (Fig. 1D). The increase of the organic input from 0 to $100 \%$ reduced from 14.96 to $8.61 \mathrm{~g}$ $\mathrm{kg}^{-1}$ of leaf sulfur. In nitrogen treatments, the $S$ contents in the passion fruit leaves did not fit any regression model, presenting a mean value of $12.13 \mathrm{~g} \mathrm{~kg}^{-1}$.

The results are in agreement with Nascimento et al. (2011) that recorded levels of $S$ between 9 and $15 \mathrm{~g} \mathrm{~kg}^{-1}$ in passion fruit plants treated with increasing levels of biofertilizer and fertilization with NPK. Cavalcante et al. (2012b) determined $\mathrm{S}$ contents close to $10 \mathrm{~g} \mathrm{~kg}^{-1}$ in the leaf dry matter of passion fruit plants under the application of bovine liquid manure. In both situations, both the contents of the present work and the authors mentioned above are greater than the range accepted as sufficient to the culture that 3 to $4 \mathrm{~g} \mathrm{~kg}^{-1}$ (Malavolta et al., 1997). As the main source of sulfur to the plants is the organic matter, the manure applied in the preparation of the pit and the biofertilizer (Additional Table 2) may have increased the levels of this element in the dry leaf matter of the plants.

\section{Micronutrient and sodium contents in leaf dry matter of yellow passion fruit plants}

The increase in bovine biofertilizer linearly increased leaf boron content from 25.8 to $59.2 \mathrm{mg} \mathrm{kg}^{-1}$ and from 50.5 to $58.7 \mathrm{mg} \mathrm{kg}^{-1}$, respectively, in soil plants without and with nitrogen fertilization (Fig. 2A). The increases of $B$ were $129.5 \%$ and $16.2 \%$, between the plants of the soil without and $100 \%$ and without and with $41 \%$ of the concentration of the biofertilizer in the soil without and with addition of nitrogen and, in general, with superiority in nitrogen treatments.

The results showed that, at the beginning of flowering, the plants had adequate levels of boron that is, inserted in the range of 40 to $50 \mathrm{mg} \mathrm{kg}$ (Malavolta et al., 1997). Comparatively, the values exceeded the variation of 20.9 to $31.9 \mathrm{mg} \mathrm{kg}^{-1}$ in plants grown in the soil with bovine biofertilizer and mineral fertilization with NPK (Nascimento et al., 2011). The adequate supply of B plants is due in part to the high available levels of the soil element before starting the experiment (Additional Table 1), to the increases provided by the manure used in the preparation of the pits and to the bovine biofertilizer supplied one week before planting and every 90 DAT until the end of the experiment. Copper contents increased from 6.95 to $17.7 \mathrm{mg} \mathrm{kg}^{-1}$ with increasing addition of organic matter in the soil with nitrogen. In the treatments without addition of $\mathrm{N}$ the values did not fit any mathematical model and were represented by the average content of $10.52 \mathrm{mg} \mathrm{kg}^{-1}$ (Fig. 2B). These results are superior to the 5 to $8 \mathrm{mg} \mathrm{kg}^{-1}$ variation recorded by Rodrigues et al. (2009) in passion fruit plants treated with biofertilizer "supermagro" and potassium, but are well below the $93.3 \mathrm{mg} \mathrm{kg}^{-1}$ presented by Cavalcante et al. (2008) in yellow passion fruit plants treated with bovine biofertilizer. Yellow passion fruit adequately supplied with copper should contain between 10 and $20 \mathrm{mg} \mathrm{kg}^{-1}$ (Malavolta et al., 1997).

This means that in the soil without addition of mineral $\mathrm{N}$ (urea $45 \% \mathrm{~N}$ ) the plants were adequately supplied to the element, but, the soil plants with $\mathrm{N}$, except under the biofertilizer levels above $60 \%$, were unbalanced in $\mathrm{Cu}$. The increase of copper in the plants due to the levels of bovine biofertilizer in the soil with $\mathrm{N}$ is a response of the greater availability of the element in the soil due to the higher concentration of the doses. On the other hand, the addition of $\mathrm{N}$ to the soil accelerates the microbial activity and the decomposition of the organic matter releasing copper to soil solution, in addition to the nitrogen causing antagonism with the copper, reducing its absorption (Ranade-Malvi, 2011).

The leaf content of iron did not respond to any of the sources of variation and the average content was $96 \mathrm{mg} \mathrm{kg}^{-1}$, which indicates deficiency of the orchard at the beginning of the flowering of the plants and according to Malavolta et al. (1997), passion fruit requires between 120 and $200 \mathrm{mg}$ of micronutrient per $\mathrm{kg}$ of dry matter leaves.

In the soil without nitrogen addition, the manganese contents were reduced from 336.31 to $191.89 \mathrm{mg} \mathrm{kg}^{-1}$ by increasing the biofertilizer provided. On the other hand, in the soil with Mn levels were elevated from 205.46 to 292.98 $\mathrm{mg} \mathrm{kg}^{-1}$ in the soil without plants and at the estimated doses of $47.7 \%$ of bovine biofertilizer (Fig. 2C). These values significantly exceed the average content of $23.3 \mathrm{mg} \mathrm{kg}^{-1}$ of micronutrient in yellow passion fruit plants treated with bovine biofertilizer (Cavalcante et al., 2008).

The reduction of manganese contents in the plants of treatments without $\mathrm{N}$ could have been provided by the reduction in the absorption of the element due to the lower availability in the soil of the respective treatments. The increase of the bovine biofertilizer in the soil can reduce the availability of micronutrients due to the complexation as recorded by Primo et al. (2011). In the soil with nitrogen, the organic matter decomposition is almost always faster and should favor the microbial action resulting in greater mineralization of nutrients, so the treatments with the presence of mineral $\mathrm{N}$ provided higher levels of manganese in relation to the soil without supply. At the beginning of the flowering period, the plants had foliar levels of manganese below the $400-600 \mathrm{mg} \mathrm{kg}^{-1}$ range and were therefore deficient in the micronutrient (Malavolta et al., 1997). However, the values exceed the variation of 121.42 to $145.60 \mathrm{mg} \mathrm{kg}^{-1}$ of leaf $\mathrm{Mn}$ presented by Menezes et al. (2012) in yellow passion fruit fertilized with bovine biofertilizer. The amplitude of 110 to $135 \mathrm{mg} \mathrm{kg}^{-1}$ obtained by Gondim et al. (2009) in yellow passion fruit under mineral fertilization with NPK.

Despite the significant action of the interaction between bovine $\times$ nitrogen biofertilizer, the zinc leaf contents did not fit any mathematical model and, therefore, were represented by the average values 44,69 and $37,15 \mathrm{mg} \mathrm{kg}^{-1}$, respectively, in the soil plants without and with nitrogen (Fig. 2D). Despite the lack of adequacy to the regression models, mean values are higher than the 25.13 and 28.86 $\mathrm{mg} \mathrm{kg}^{-1}$ of $\mathrm{Zn}$ presented by Pacheco et al. (2017) in passion fruit manure fertilized with cattle manure in Visconde do Rio Branco, Minas Gerais. 

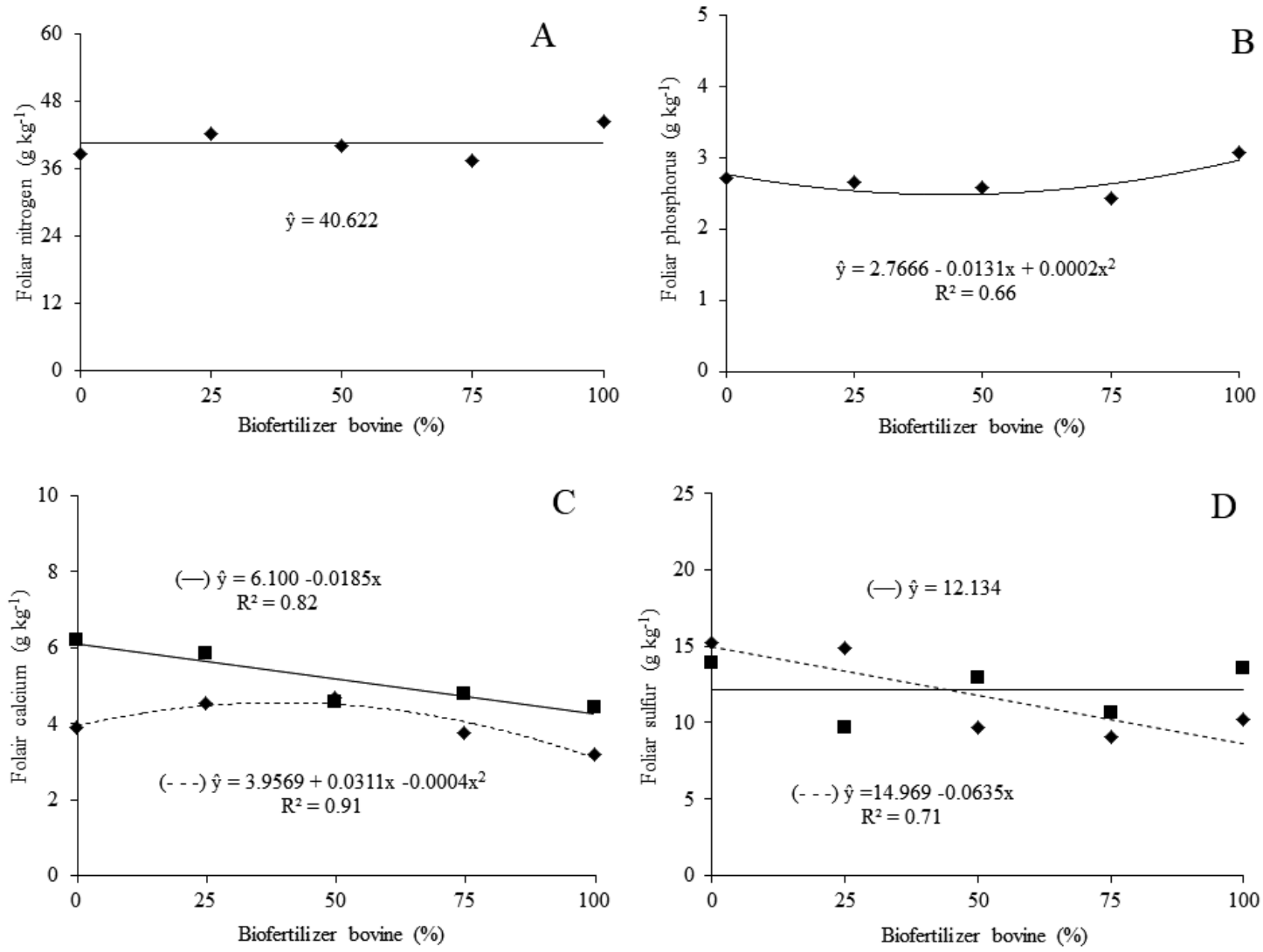

Fig 1. Content of nitrogen (A) and phosphorus (B) in dry matter leaf of yellow passion fruit plants, as a function of bovine biofertilizer, and calcium (C) and sulfur (D), as a function of the interaction between bovine biofertilizer and nitrogen applied to soil.
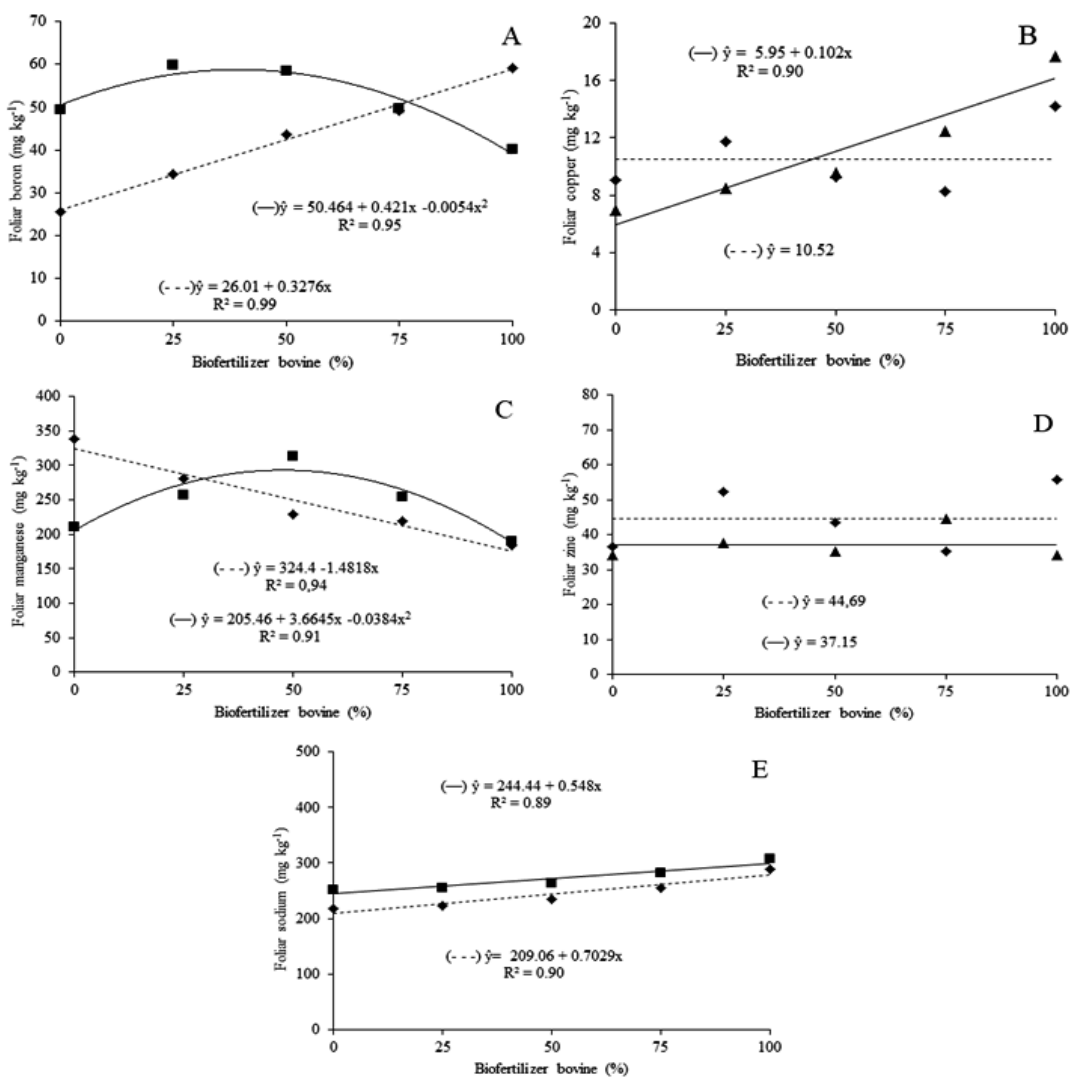

Fig 2. Content of boron (A), copper (B), manganese (C), zinc (D) and sodium (E) in dry matter leaf of yellow passion fruit plants, as a function of the interaction between bovine biofertilizer and nitrogen applied to soil. 


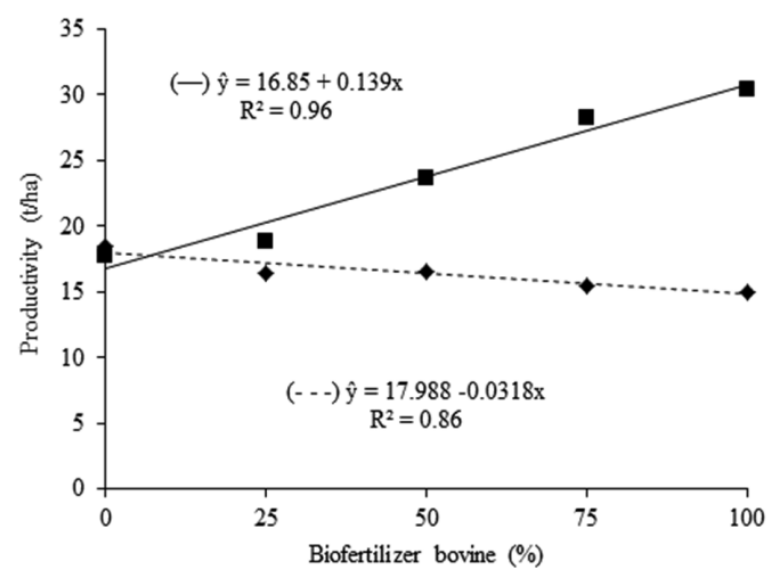

Fig 3. Fruit productivity of yellow passion fruit fruits, as a function of the interaction between bovine biofertilizer and nitrogen applied to soil.

Yellow passion fruit plants were nutritionally balanced in zinc, with contents between 25 and $40 \mathrm{mg} \mathrm{kg}^{-1}$ (Malavolta et al., 1997). Ahmed et al. (2011), reported that there are microorganisms in the biofertilizers that solubilize the micronutrients, mainly the zinc, resulting in greater availability in the soil solution and greater absorption by the plants. The leaf contents of sodium independently of the soil without and with nitrogen increased linearly as a function of the levels of bovine biofertilizer (Fig. 2E). The contents were elevated from 209.6 to $279.35 \mathrm{mg} \mathrm{kg}^{-1}$ and from 244.44 to $299.24 \mathrm{mg} \mathrm{kg}^{-1}$ with increases of 33.6 and $22.4 \%$ among the plants without and with the highest level of biofertilizer, respectively, in the soil without and with addition of nitrogen in the form of urea.

Although it is not an essential nutrient to yellow passion fruit, the sodium content accumulated in the leaves generally exceeds the sum of the micronutrients boron, copper and iron. On the other hand, despite this superiority, the contents are markedly lower than the variation of 1.3 to $3.1 \mathrm{~g} \mathrm{~kg}^{-1}$ reported by Cavalcante et al. (2008) and from 2.2 to $2.5 \mathrm{~g} \mathrm{~kg}^{-1}$ by Gondim et al. (2009) in the same crop, respectively treated with bovine biofertilizer and conventional mineral fertilization, both situations under irrigation with water without risk of salinity to the plants.

\section{Fruits Productivity}

The increase of the biofertilizer doses associated with the application of nitrogen increases the fruit yield of the plants, but the isolated application of the organic input reduces the productive capacity of the crop (Fig. 3). In the nitrogen treatments the yield was elevated from 16.85 to $30.75 \mathrm{t} \mathrm{ha}^{-1}$ corresponding to a gain of $82.5 \%$. This increase, in response to the bovine and nitrogen biofertilizer association, is in agreement with Cavalcante et al. (2012b) and Oliveira et al. (2014) concluding that yellow passion fruit and finger pepper (Capsicum baccatum) produced more in the soil with bovine biofertilizer and mineral fertilization with NPK.

On the other hand, in the soil without nitrogen the productivity was reduced from 17.99 to $14.81 \mathrm{t} \mathrm{ha}^{-1}$, with the increase of the bovine biofertilizer levels, resulting in a loss of $17.7 \%$. This situation differs from the literature in which the bovine biofertilizer, in the great majority of cases, stimulates the growth and production of the plants as observed by Aguiar et al. (2017) in yellow passion fruit. The reduction can be a response of the increase in the population of microorganisms in the soil, such as fungi and bacteria, 20 or 25 days after the organic input. Morocco et al. (2012) that initially consume or immobilize N and K, including phosphorus (Mohammadi and Sohrabi, 2012) and may induce temporary nutritional deficiency and, in effect, inhibit growth and productive capacity of plants.

The superiority of the plants with bovine biofertilizer and nitrogen in relation to those treated with only the organic input, even considering the beneficial effects (Oliveira et al, 2014), the respective input does not replace the mineral fertilizers in the yellow passion fruit crop, as presented by Cavalcante et al. (2012b) in plantations, respectively treated with biofertilizer and NPK, biofertilizer. Despite the decline in nitrogen-free soil plants, except for the lowest value (14.81 $\mathrm{t}$ ha-1), the other yields exceed the Brazilian productivity average that is below $15 \mathrm{t} \mathrm{ha}^{-1}$ (Furlaneto et al., 2014; IBGE, 2017). The yields of Aguiar et al. (2017), Pacheco et al. (2017) and Uchôa et al. (2018) that were 12.5, 9.2 and $5 \mathrm{t} \mathrm{ha}^{-1}$, respectively, in plants under organic fertilization cultivated in the States of Paraíba, Minas Gerais and Acre.

\section{Materials and Methods}

\section{Characterization of experimental location and soil}

The experiment was conducted at the Macaquinhos property, Remígio municipality, Paraíba State, Brazil; at $6^{\circ}$ $53^{\prime} 00^{\prime \prime}$ south latitude, $36^{\circ} 02^{\prime} 00^{\prime \prime}$ west of Greenwich meridian, at an altitude of $470 \mathrm{~m}$. The climate of the municipality is type As', hot and humid (Alvares et al., 2013), with average temperature of $24^{\circ} \mathrm{C}$, relative humidity of the air ranging from 70 to $80 \%$, with average annual rainfall less than $900 \mathrm{~mm}$ and rainy season concentrates between the months of March and July.

The soil of the experimental area, by the criteria of the Brazilian Soil Classification System - SiBCS (Embrapa, 2018), is a Cambisol, well drained and sandy texture. When considering that the highest proportion of roots of yellow passion fruit is concentrated in the first $0.4 \mathrm{~m}$, soil samples were collected in the $0-0.4 \mathrm{~m}$ layer for chemical characterization of fertility and physical (Additional Table 1) using the suggested methodologies by Embrapa (2017). 


\section{Experiment set up and conduction}

The experimental design was in randomized blocks, in the factorial scheme $5 \times 2$, with three replications and nine plants per plot. The sources of variation refer to five levels of bovine biofertilizer in the soil without and with nitrogen in the form of urea ( $45 \%$ of $N$ ). The yellow passion fruit used in the experiment was the "Guinezinho" access, which is widely cultivated in the State of Paraíba, because it presents rusticity to the climatic inclement weather of the region and productivity above the national average when well managed (Aguiar et al., 2017).

The bovine biofertilizer (B) was obtained by anaerobic fermentation of equal volumes of $100 \mathrm{~L}$ of fresh manure from lactating cows and $100 \mathrm{~L}$ of non-saline and nonchlorinated water for 30 days in the shade (Santos, 1992), analyzed chemically as irrigation water (Richards, 1954) (Additional Table 2) and applied one week before and every 90 days after transplanting the seedlings - DAT diluted in water $(W)$ at the levels $0 \%(O B+4 W), 25 \%(1 B+3 W), 50 \%$ $(2 B+2 W), 75 \%(3 B+1 W)$ and $100 \%(4 B+0 W)$ of each mixture in an area of $0.8 \mathrm{~m}^{2}$ of the plant stem in the center of the area.

The pits were opened in the dimensions of $0.4 \times 0.4 \times 0.4 \mathrm{~m}$ in spacing of $2.5 \times 4.0 \mathrm{~m}$. The substrate consisted of material from the first $0.2 \mathrm{~m}$ of soil, together with $10 \mathrm{dm} 3$ of $P, K$, $\mathrm{Ca}^{2+}$ and $\mathrm{Mg}^{2+}$ rich manure. The bovine manure was chemically characterized (Embrapa, 2017) and had $\mathrm{pH}=8.1$; $\mathrm{P}=722$ and $\mathrm{K}^{+}=2,710 \mathrm{mg} \mathrm{dm}{ }^{-3} ; \mathrm{Na}^{+}=0.13 ; \mathrm{Ca}^{2+}=8.05 ; \mathrm{Mg}^{2+}$ $=4.81 ; \mathrm{H}^{+}+\mathrm{Al}^{3+}=4.04 \mathrm{cmol}_{\mathrm{c}} \mathrm{dm}^{-3} ; \mathrm{C}=16.46 ; \mathrm{OM}=28.37 ; \mathrm{N}$ $=1.44 \mathrm{~g} \mathrm{~kg}^{-1}$ and $\mathrm{S}=0.071 \mathrm{~kg} \mathrm{~kg}^{-1}$. As for the micronutrients contained the contents of $0.14,1.16 ; 20.37 ; 40.48$ and 5.31 $\mathrm{mg} \mathrm{dm}{ }^{-3}$ respectively of $\mathrm{B}, \mathrm{Cu}, \mathrm{Fe}, \mathrm{Mn}$ and $\mathrm{Zn}$. Because bovine manure is rich in $\mathrm{P}, \mathrm{K}, \mathrm{Ca}^{2+}$ and $\mathrm{Mg}^{2+}$, none of the nutrients were supplied to the pits.

The transplanting was done in the first week of September 2013 when the seedlings were with aged 50 days and were obtained of the fruit seeds well developed in size, oblique shape and mass. The system of conduction of the plants was in a simple flat-bladed no. 12 wire, installed on top of cuttings at a height of $2.2 \mathrm{~m}$. Irrigation was done by drip irrigation with two emitters per plant, Katif type and mean flow rate of $3.75 \mathrm{~L} \mathrm{~h}^{-1}$, installed one to the East and one to the West of the stem in the distance of $0.20 \mathrm{~m}$, providing daily $4 \mathrm{~L}_{\text {plant }}{ }^{-1}$ day $^{-1}$ until the first 60 DAT, $8 \mathrm{~L}_{\text {plant }}{ }^{-1}$ day $^{-1}$ of the 60 DAT at flowering and $12 \mathrm{~L} \mathrm{plant}^{-1}$ day $^{-1}$ of the flowering until the end of the experiment (Gondim et al., 2009).

The mineral fertilization after the transplanting of the seedlings was done using the suggestions of Borges and Souza (2010), but because the cattle manure is concentrated in $\mathrm{K}$ and $\mathrm{P}$, the nutrients were applied from 90 DAT. Nitrogen from urea was applied at the level of $10 \mathrm{~g}^{\text {plant }}{ }^{-1}$ of $\mathrm{N}$ at 30 and 60 DAT, after that age at the monthly dosage of $20 \mathrm{~g} \mathrm{~N}$ plant $^{-1}$ until the penultimate month of the experiment. From 90 DAT, potassium in the form of potassium chloride (50\% K) was applied at the same frequencies and dose of nitrogen $(1 \mathrm{~N}: 1 \mathrm{~K})$ and phosphorus in the form of single superphosphate $\left(20 \% \mathrm{P}_{2} \mathrm{O}_{5}, 20 \% \mathrm{Ca}^{2+}, 12 \% \mathrm{~S}\right)$ at the level of $40 \mathrm{~g}$ plant ${ }^{-1}$ of $\mathrm{P}_{2} \mathrm{O}_{5}$ at 90 DAT and every three months. The values total 15 fertilizations with nitrogen, four with phosphorus and 13 with potassium, totaling 280, 160 and
$260 \mathrm{~g}$ of $\mathrm{N}, \mathrm{P}_{2} \mathrm{O}_{5}$ and $\mathrm{K}_{\text {plant }}{ }^{-1}$ in the experimental period. These values total 622,800 and $520 \mathrm{~kg} \mathrm{ha}^{-1}$ year $^{-1}$, respectively of urea, simple superphosphate and potassium chloride.

\section{Variables analyzed}

At the beginning of flowering, at 110 DAT, three nitrogen fertilizations $(30,60$ and 90 DAT), one potassium at 90 DAT and two applications of the bovine biofertilizer (one week before and 90 DAT) were collected from each (N, P, K, Ca, $\mathrm{Mg}$ and $\mathrm{S})$, micronutrients ( $\mathrm{N}, \mathrm{P}, \mathrm{K}, \mathrm{Ca}, \mathrm{Mg}$, and $\mathrm{S}$ ), respectively, from the terminal shoot of the healthy medium productive branches (Malavolta et al., 1997). B, Zn, Mn and $\mathrm{Cu}$ ) and sodium in the dry matter using the methodologies recommended by Embrapa (2017).

The fruits were harvested at the beginning of physiological maturation (Vianna-Silva et al., 2010), in order to obtain the yield of the crop through the product between the production per plant and the number of plants per hectare $\left(1,000\right.$ plants $\left.h a^{-1}\right)$, expressed in $\mathrm{t} \mathrm{ha}^{-1}$.

\section{Statistical analysis}

The data were submitted to analysis of variance by the $\mathrm{F}$ test ( $p<0.05)$. The averages for nitrogen fertilization were compared by the $\mathrm{F}$ test, which is conclusive for two factors from the same source of variation. The means referring to levels of bovine biofertilizer were evaluated by regression $(p \geq 0.01$ and $p \geq 0.05)$. The data were analyzed using SAS statistical software version 8.0.

\section{Conclusion}

Plants at the beginning of flowering were balanced in $\mathrm{N}, \mathrm{Mg}$, $\mathrm{S}, \mathrm{B}, \mathrm{Cu}$ and $\mathrm{Zn}$, but deficient in $\mathrm{P}, \mathrm{K}, \mathrm{Ca}, \mathrm{Fe}$ and $\mathrm{Mn}$. The highest yields were obtained in the plants of the treatments with bovine biofertilizer and nitrogen from urea. The bovine biofertilizer in the soil without nitrogen inhibits the productive capacity of the yellow passion fruit "Guinezinho" access. The bovine biofertilizer does not replace nitrogen in the cultivation of yellow passion fruit.

\section{Acknowledgment}

At Conselho Nacional de Desenvolvimento Científico e Tecnológico (CNPq) for funding the research grant and the researchers from Instituto Nacional de Ciência e Tecnologia em Salinidade (INCTSal).

\section{References}

Aguiar AVM, Cavalcante LF, Silva RM, Dantas TAG, Santos EC (2017) Effect of biofertilization on yellow passion fruit production and fruit quality. Rev Caatinga, 30: 136-148.

Ahmed MAA, Ahmed G, Mohamed MH, Tawfik MM (2011) Integrated effect of organic and biofertilizers on wheat productivity in new reclaimed sandy soil. Res J Agric Biol Sci. 7:105-114.

Alvares CA, Stape JL, Sentelhas PC, Gonçalves JLM, Sparovek G (2013) Köppen's climate classification map for Brazil. Meteorol

$\mathrm{Z}$.

22 711-728. 
Borges AL, Souza LD (2010) Recomendações de calagem e adubação para maracujazeiro. $1^{\text {st }}$. Cruz das Almas: Embrapa Mandioca e Fruticultura, $4 \mathrm{p}$.

Cavalcante IHL, Cavalcante LF, Santos GD, BeckmannCavalcante MZ, Silva SM (2012a) Impact of biofertilizers on mineral status and fruit quality of yellow passion fruit in Brazil. Commun. Soil Sci Plant Anal. 43: 2027-2042.

Cavalcante LF, Cavalcante IHL, Rodolfo Júnior F, BeckmannCavalcante MZ, Santos GP (2012b) Leaf-macronutrient status and fruit yield of biofertilized yellow passion fruit plants. J Plant Nutr. 35:176-191.

Cavalcante LF, Cavalcante IHL, Santos GD (2008) Micronutrient and sodium foliar contents of yellow passion plants as a function of biofertilizers. Fruits. 63:2736.

Cavichioli JC, Narita N, Nasser MD, Takata WHS (2017) Desenvolvimento e produtividade de maracujazeiro amarelo enxertado na região de Presidente Prudente, SP. Cul. Agron. 26: 61-68.

Embrapa - Empresa Brasileira de Pesquisa Agropecuária (2017) Manual de Métodos de Análise de Solos. $3^{\text {rd }}$ Brasília: Embrapa Solos, 573p.

Embrapa - Empresa Brasileira de Pesquisa Agropecuária (2018) Sistema Brasileiro de Classificação de Solos. $5^{\text {th }}$. Brasília: Embrapa Solos, 356p.

Furlaneto FPB, Esperancini MST, Martins, NA, Okamoto F, Vidal AA, Bueno OC (2014) Análise energética do novo sistema de produção de maracujá amarelo na região de Marília-SP. Ciênc. Rural 44: 235-240.

Instituto Brasileiro de Geografia e Estatística (2017) Lavoura permanente 2017 - maracujá.

<http://www.ibge.gov.br/estadosat/temas.php?sigla=ba\&te ma=lavourapermanente2017> (Accessed December 1, 2018)

Lehmann J, Kleber M (2015) The contentious nature of soil organic matter. Nature. 528: 60-68.

Li R, Tao R, Ling N, Chu G (2017) Chemical, organic and biofertilizer management practices effect on soil physicochemical property and antagonistic bacteria abundance of a cotton field: Implications for soil biological quality. Soil Tillage Res. 167: 30-38.

Malavolta E, Vitti GC, Oliveira AS (1997) Avaliação do estado nutricional das plantas, princípios e aplicações. $2^{\text {nd }}$. Piracicaba: Potafos 319p.

Marrocos STP, Novo Junior J, Grangeiro LC, Ambrosio MMQ, Cunha APA (2012) Composição química e microbiológica de biofertilizantes em diferentes tempos de decomposição. Rev Caatinga. 25: 34-43.

Meletti LMM (2011) Avanços na cultura do maracujá no Brasil. Rev Bras Frutic. 33: 83-91.

Menezes EF, Cavalcante LF, Mesquita FO, Campos VB, Dantas TAG (2012) Composição mineral do maracujazeiro amarelo em resposta ao biofertilizante bovino e cloreto de potássio no solo. Rev Bras Ciênc Agrar. 7:260-268.
Mohammadi K, Sohrabi Y (2012) Bacterial biofertilizers for sustainable crop production: A review. Res J Agric Biol Sci. 7:307-316.

Nascimento JAM, Cavalcante LF, Dantas SAG, Silva SA (2011). Estado nutricional de maracujazeiro-amarelo irrigado com água salina e adubação organomineral. Rev Bras Frut. 33:729-735.

Natale W, Rozane DE, Parent LE, Parent SE (2012) Acidez do solo e calagem em pomares de frutíferas tropicais. Rev Bras Frut. 34:1294-1306.

Oliveira JR, Gomes RLF, Araújo ASF, Marini FS, Lopes JB, Araújo RM (2014) Estado nutricional e produção da pimenteira com uso de biofertilizantes líquidos. Rev Bras Eng Agric Ambient. 8:1241-1246.

Pacheco ALV, Pagliarini MF, Freitas GB, Santos RHS, Serrão JE, Zanuncio, JC (2017) Mineral composition of pulp and production of the yellow passion fruit with organic and convention I fertilizers. Food Chem. 217:425-430.

Primo DC, Menezes RSC, Silva TO (2011) Substâncias húmicas da matéria orgânica do solo: uma revisão de técnicas analíticas e estudos no nordeste brasileiro. Sci Plena. 7:1-13.

Renade-Malvi U (2011) Interaction of micronutrients with major nutrients with special reference to potassium. Karnataka J. Agric. Sci. 24:106-109.

Richards LA (1954) Diagnostico y rehabilitación de suelos salinos y sódicos. México: Departamento de Agricultura de los Estados Unidos de América, (Manual de Agricultura, 60). 174p.

Rodrigues AC, Cavalcante LF, Oliveira AP, Sousa JT, Mesquita FO (2009) Produção e nutrição mineral do maracujazeiroamarelo em solo com biofertilizante supermagro e potássio. Rev. Bras. Eng. Agric. Ambient. 13: 117-124.

Santos ACU (1992) Biofertilizante líquido: defensivo agrícola da natureza. $1^{\text {st }}$. Niterói: Emater, 162p.

Silva Júnior GB, Cavalcante IHL, Albano FG, Osajima JA (2013) Estado nutricional e clorofila foliar do maracujazeiroamarelo em função de biofertilizantes, calagem e adubação com N e K. Rev. Cienc. Agrar. 36:163-173.

Taiz L, Zeiger E, Møller IM, Murphy A (2017) Fisiologia e desenvolvimento vegetal. $6^{\text {th }}$. Porto Alegre: Artmed, $858 \mathrm{p}$.

Uchôa TL, Araújo Neto SE, Selhorst PB, Rodrigues MJS, Galvão RO (2018) Yellow Passion fruit performance in organic crop under mulch. Rev. Bras. Frut. 40:212-219.

Venâncio JB, Rodrigues ET, Silveira MV, Araújo WF, Chagas EA, Castro AM (2013) Produção, qualidade dos frutos e teores de nitrogênio foliar em maracujazeiro-amarelo sob adubação nitrogenada. Científica. 41: 11-20.

Vianna-Silva T, Lima RV, Azevedo IG, Rosa RCC, Souza MS, Oliveira JG (2010) Determinação da maturidade fisiológica de frutos de maracujazeiro-amarelo colhidos na região norte do Estado do Rio de Janeiro, Brasil. Rev Bras Frut. 32: 57-66. 